\title{
Guiding recombinant antivenom development by omics technologies
}

\section{Laustsen, Andreas Hougaard}

\section{Published in:}

New Biotechnology

Link to article, DOI:

10.1016/j.nbt.2017.05.005

Publication date:

2018

Document Version

Peer reviewed version

Link back to DTU Orbit

Citation (APA):

Laustsen, A. H. (2018). Guiding recombinant antivenom development by omics technologies. New Biotechnology, 45, 19-27. https://doi.org/10.1016/j.nbt.2017.05.005

\section{General rights}

Copyright and moral rights for the publications made accessible in the public portal are retained by the authors and/or other copyright owners and it is a condition of accessing publications that users recognise and abide by the legal requirements associated with these rights.

- Users may download and print one copy of any publication from the public portal for the purpose of private study or research.

- You may not further distribute the material or use it for any profit-making activity or commercial gain

- You may freely distribute the URL identifying the publication in the public portal

If you believe that this document breaches copyright please contact us providing details, and we will remove access to the work immediately and investigate your claim 


\title{
Manuscript Details
}

Manuscript number

Title

Article type
NBT_2017_136

Guiding recombinant antivenom development by omics technologies

Review Article

\begin{abstract}
In this review, the different approaches that have been employed with the aim of developing novel antivenoms against animal envenomings are presented and discussed. Reported efforts have focused on the use of innovative immunization strategies, small molecule inhibitors against enzymatic toxins, endogenous animal proteins with toxinneutralizin capabilities, and recombinant monoclonal antibodies. Harnessing either of these approaches, antivenom development may benefit from an in-depth understanding of venom compositions and which toxins that are essential to neutralize in an envenoming case. Focus is thus also directed towards the different omics technologies (particularly venomics, antivenomics, and toxicovenomics) that are being used to uncover novel animal toxins, shed light on venom complexity, and provide directions for how to determine the medical relevance of individual toxins within whole venoms. Finally, techniques for assessing antivenom specificity and cross-reactivity are reviewed, with special focus on antivenomics and high-density peptide microarray technology.
\end{abstract}

Keywords

Corresponding Author

Corresponding Author's Institution

Order of Authors

Suggested reviewers
Toxinology; recombinant antivenom; toxicovenomics; antivenomics; high-density peptide microarray technology;

Andreas Laustsen

Technical University of Denmark

Andreas Laustsen

Juan J. Calvete, Manuela Pucca, Nicholas Casewell, Bruno Lomonte

\section{Submission Files Included in this PDF}

\section{File Name [File Type]}

Cover letter, New Biotechnology.docx [Cover Letter]

Laustsen. Antibody discovery guided by venom proteomics v5.doc [Manuscript File]

Highlights.docx [Highlights]

\section{Submission Files Not Included in this PDF}

\section{File Name [File Type]}

Figure 1. Toxicovenomics.png [Figure]

Figure 2. Antivenomics.png [Figure]

Figure 3, peptide microarrays.png [Figure]

To view all the submission files, including those not included in the PDF, click on the manuscript title on your EVISE Homepage, then click 'Download zip file'. 
April $12^{\text {th }}, 2017$

Dr. Mike Taussig

Editor-in-Chief

New Biotechnology

Dear Dr. Mike Taussig

Thank you for your encouragement to publish in the journal. Please find attached the manuscript entitled 'Guiding recombinant antivenom development by omics technologies', to be considered for publication as a review article in New Biotechnology.

In recent year, there has been an increased focus on how to overcome the challenge of snakebite and bring novel antivenoms to poor rural parts of the tropical world. A few reviews are already available in the field (of which I have co-authored some), however, these are focused on the individual efforts and specific toxinneutralizing molecules, antibodies, or sera, and fail to provide an overview of the omics technologies employed to guide their development. Here, I have aimed to provide such an overview, and bring more clarity to how omics technologies interplay with toxinology and how these may be employed to guide medicinal chemistry and biotechnological efforts within antivenom development. It is my personal experience that too many research efforts have been unsuccessful, as they have attempted to develop toxintargeting molecules without taking the complexity of venom and the often inverse relationship between toxicity and immunogenicity into account. It is my belief that an overview of how omics technologies can be harnessed in antivenom development will be useful for particularly drug development researchers (and graduate students) who are new in the field, and who need to gain an understanding of venoms and how these may be viewed and analyzed as drug targets.

I therefore hope that you will take this article into consideration.

Sincerely yours,

Dr. Andreas H. Laustsen 
Address for correspondence:

Dr. Andreas H. Laustsen

Postdoctoral Fellow

*ahola@bio.dtu.dk 


\section{Abstract}

22 In this review, the different approaches that have been employed with the aim of developing novel

23 antivenoms against animal envenomings are presented and discussed. Reported efforts have focused 24 on the use of innovative immunization strategies, small molecule inhibitors against enzymatic 25 toxins, endogenous animal proteins with toxin-neutralizin capabilities, and recombinant monoclonal 26 antibodies. Harnessing either of these approaches, antivenom development may benefit from an in27 depth understanding of venom compositions and which toxins that are essential to neutralize in an 28 envenoming case. Focus is thus also directed towards the different omics technologies (particularly 29 venomics, antivenomics, and toxicovenomics) that are being used to uncover novel animal toxins, 30 shed light on venom complexity, and provide directions for how to determine the medical relevance 31 of individual toxins within whole venoms. Finally, techniques for assessing antivenom specificity 32 and cross-reactivity are reviewed, with special focus on antivenomics and high-density peptide 33 microarray technology. 


\section{Introduction}

Among the tropical diseases, snakebite envenoming remains one of the most neglected, causing mortality and morbidity to thousands of victims worldwide each year [1-3]. In addition, envenomings by other species, particularly scorpions and spiders, also constitute a medically important challenge for public health [4-7]. Modern approaches based on biotechnology and medicinal chemistry are starting to see the light of day through neutralization of animal toxins by monoclonal antibodies (mAbs) and small molecule inhibitors [8,9]. Yet, serum-based antivenom derived from immunized animals is currently the only therapeutically effective treatment option against most animal envenomings [10]. Antivenom is thus one of the few biological therapies that have not yet entered the modern era of biologics, despite the presence of an overwhelmingly large patient population. Although part of the explanation for the lack of innovation within antivenom development may be attributed to the poor financial incentive for investment in the field, the sheer complexity of animal venoms may also hold part of the answer. Not only is each venom a complex mixture of toxins, but venoms are highly diverse across the known 725 venomous snake species [8], 2000 scorpion species, and 44,000 spider species [9]. As an example and rough estimation, it has previously been suggested that between 19,000-25,000 toxins may exist in the venoms of the two snake families, Elapidae and Viperidae, that contain the species of the highest medical relevance for human health [8]. Although neutralization of many of these toxins and toxins from other animal species may not individually be medically essential in every envenoming case [11], such numbers strongly support the notion that animal venoms are among the most complex drug targets known to man. In this review, novel strategies for developing modern envenoming therapies are reviewed with special focus on how omics (particularly venomics [12] and toxicovenomics [13]) technologies can be employed to guide discovery of antibodies capable of neutralizing medically relevant toxins. 


\section{Neutralization of animal toxins}

60 Animal venom toxins are proteinaceous and have evolved primarily to subdue prey, as well as to

61 deter predators. Animal toxins can exert a myriad of different pathophysiological effects in victims 62 of envenoming, including systemic neurotoxicity, haemotoxicity, myotoxicity, and cytotoxicity, 63 manifesting clinically as flaccid paralysis, involuntary muscle contraction, various coagulopathies, 64 nephrotoxicity, and local tissue damage including necrosis [14,15]. Different approaches have been

\section{Optimizing antisera by next generation immunization technology}

Two of the challenges in current antivenom production include procurement of venoms and obtaining a balanced response against the medically relevant toxins within a venom [16]. Additionally, intraspecies venom variation is a common phenomenon [17,18], which may further complicate design of effective immunization mixtures. Although differences in antibody responses also occur among immunized animals for antivenoms, variation in response can to some extent be controlled using standardized immunogens, such as (multi)epitope DNA strings, synthetic peptides, or recombinant toxins [6]. Using such molecules also has the advantage that the immunization mixture can be designed to contain only those immunogens of medical relevance to humans. A prominent example of the successful use of DNA strings for immunization was reported in 2006, where antisera against toxins of the two vipers, Echis ocellatus and Cerastes cerastes, were successfully raised by immunizing mice in the epidermal layer of their abdominal region with a 
83 multiepitope DNA immunogen using a GeneGun [19]. Using a synthetic peptide containing continuous and discontinuous epitopes derived from the Centruroides noxius (scorpion) Cn2 toxin, researchers in another study succeeded in raising efficacious antiserum in rabbits [20]. Similarly, rabbits have also been immunized with a recombinant, non-toxic version (a toxoid) of the TsNTxP toxin from Tityus serrulatus venom, which could protect rabbits against $20 \mathrm{LD}_{50} \mathrm{~s}$ of whole venom from this scorpion [21]. Nevertheless, despite these and many more examples of the successful use of such modern immunization technologies, the final products of their use are still serum-based medicines that are costly to produce and may be immunogenic to human recipients due to their heterologous nature.

\section{Using small molecule inhibitors against animal toxins}

A few dozen molecules have been reported to show inhibitory effects against various toxins from spiders, scorpions, and snakes [8,9]. Common to all these small molecule inhibitors is that they target enzymatically active toxins, either by mimicking the natural substrate or scavenging an important co-factor for the apoenzyme. Examples of toxin-inhibiting small molecules include varespladib, which effectively neutralizes phospholipase $A_{2}$ activity of many snake venoms [22], batimastat and EDTA, which chelate $\mathrm{Zn}^{2+}$ ions and thereby inhibit metalloprotease activity [23], and heparin, which may inhibit hyaluronidase activity [24-26]. However, no toxin-targeting small molecule is currently in clinical use. More details and examples of small molecule inhibitors (particularly from plants) is beyond the scope of this review and can be found elsewhere [27].

\section{Harnessing natural toxin-neutralizing proteins from animals}

Non-antibody proteinaceous molecules capable of neutralizing animal toxins have not so far been reported outside the field of snake venoms. However, for snake venoms the presence of protective 
proteins has been described in a range of different animal species, including the South American opossum, Didelphis marsupialis [28-30], snakes themselves [31-35], and ground squirrels (Spermophilus beecheyi) [36]. Some of these factors have even shown greater toxin-neutralizing capacity than commercial antivenoms, exemplified by the $97 \mathrm{kDa}$ protein and the antibothropic 111 complex derived from Didelphis marsupialis serum [30]. These proteins were 4 and 6 times more 112 potent than the commercially available antivenom against Bothrops lanceolatus venom and $B$. 113 jararaca venom, respectively [30]. Although such results are fascinating and may even seem 114 promising, two major obstacles are likely to prevent the use of these types of molecules from being 115 used as envenoming therapy. Firstly, the expression of non-standard protein formats is not always a 116 trivial matter. Given the molecular diversity of the different naturally occurring toxin-neutralizing 117 proteins, eventual expression/production would be resource-consuming to standardize (though not 118 necessarily in the distant future). Secondly, none of the toxin-neutralizing proteins are of human 119 origin; combined with the fact that many of the toxins are quite large $(>50 \mathrm{kDa})$ proteins, their 120 heterologous nature is likely to inflict adverse reactions in human recipients due to the likelihood of 121 high immunogenicity. Possibly, however, if a promising scaffold protein were to be developed with 122 low immunogenicity and able to be engineered easily to target a multitude of different toxin 123 families, it is conceivable that a molecular platform and discovery strategy could be employed for 124 development of non-antibody-based toxin-neutralizing proteins. Examples of such platform 125 technologies might include DARPins [37,38], Armadillo repeat proteins [39], affitins [40-42], 126 adhirons [43], anticalins [44], and various other protein scaffolds [45], although these molecular 127 formats are yet to be tested for their applicability for antitoxin development. 
130 Various different monoclonal antibody $(\mathrm{mAb})$ formats have been discovered and developed against

131 toxins from different animal species, including snakes, scorpions, spiders, and bees [8,9,46]. The

132 first use of a mAb capable of neutralizing a toxin was reported in 1982 using hybridoma technology

133 [47]. This IgG antibody targets toxin $\alpha$ from the Black-necked spitting cobra, Naja nigricollis.

134 Since then, 63 additional murine IgG mAbs targeting toxins from snakes, spiders, and scorpions

135 have been reported [8,9]. However, this number is unlikely to increase significantly, given the

136 prospects of using transgenic (humanized) animals capable of producing human IgGs more suitable

137 for human therapy and the advent of phage display technology. This is one of the most promising

138 avenues for development of novel recombinant antivenoms [48,49]. Most commonly, phage display

139 selection has been used to develop human single-chain variable fragments (scFvs) with important

140 examples including the development of Serrumab against the toxins, Ts1 and Ts2, from the

141 Brazilian yellow scorpion (T. serrulatus) [50,51], Afribumab targeting melittin and phospholipase

$142 \mathrm{~A}_{2} \mathrm{~S}$ in Africanized bee (Apis mellifera) venom [46], the human scFv P2B7 capable of neutralizing

143 myotoxicity from Bothrops jararacussu venom [52], and ER-5 against $\beta$-neurotoxins from

144 Centruroides scorpion venoms [53]. Other formats, including diabodies [54,55], camelid $\mathrm{V}_{\mathrm{H}} \mathrm{H}$ [56-

145 60], bispecific $\mathrm{V}_{\mathrm{H}} \mathrm{H}$ [61], and $\mathrm{V}_{\mathrm{H}} \mathrm{H}-\mathrm{Fc}$ fusions [62] have also been reported to successfully

146 neutralize a range of different toxins, particularly from scorpions and snakes. The prospect of using

147 (mixtures of) human mAbs against animal envenomings has gained increasing interest in recent

148 years. The reasons for this include the versatility of the (human) antibody scaffold, its compatibility

149 with the human immune system, the success of human antibodies in other fields [63], and the

150 demonstration that recombinant antivenoms may be produced cost-competitively by mammalian

151 cell cultivation $[64,65]$ with future production costs of antibodies likely to decrease even further

152 [66]. Despite the existence of several feasible discovery approaches (particularly using humanized 
transgenic animals, phage display, or even combined approaches), a need remains to elucidate

154 which animal toxins to focus antivenom research efforts on.

\section{Using omics technologies to establish order in venom complexity}

157 Independent of the molecular scaffold and discovery strategy employed for developing the next 158 generation of antivenoms against animal envenomings, it is critical to have a thorough 159 understanding of venom complexity and which toxins to target. For this purpose, different omics 160 technologies are increasingly being used to uncover novel animal toxins and help guide antivenom 161 development.

To date, genomes have been reported for two snakes (King cobra, Ophiophagus

163 Hannah, and Burmese python, Python molurus bivittatus) [67,68], three spiders (African social 164 velvet spider, Stegodyphus mimosarum, Brazilian white-knee tarantula, Acanthoscurria geniculate, 165 and House spider, Parasteatoda tepidariorum) [69,70], one scorpion (Manchurian scorpion, 166 Mesobuthus martensii) [71], and the honey bee (Apis mellifera) [72]. In addition, a multitude of 167 transcriptomics studies has been performed, particularly on the venom glands from snakes, 168 scorpions, and spiders [8,9]. These have all provided important evolutionary insight into the biology 169 of venomous animals and may be used to uncover novel toxins with unique functionalities. In 170 general, however, correlation between mRNA transcripts and protein expression may not always be 171 high [73], which has on several occasions shown to be the case for certain snake venoms from both 172 the viper and elapid families [74-76]. Therefore, genomic and transcriptomic studies may benefit 173 from combination with proteomics to establish a full overview of a venom. 
venom proteomes [79,80]. Venomics can be performed both by bottom-up [81] and top-down approaches, with the latter having the benefit of being able to distinguish between closely related toxin isoforms [82]. By mid-2015, approximately 140 snake venoms had undergone a venomics analysis [8]. Since then, this number has been growing steadily with new studies on venomous 181 snakes from Asia, Africa, Australia, Europe, and Latin America [82-89]. Fewer venomics studies 182 have been performed on venoms from spiders, scorpions [9], bees, and insects, owing to the 183 amounts of venom needed for estimating quantitative venom proteomes, and the scarcity of venoms from most of these rather small creatures. Therefore, most of the proteomic studies performed on venoms from these smaller species are qualitative in nature and only provide a catalog of toxins present in the venoms with unknown abundances.

Venomics provides a good descriptive overview of venom. However, to fully gain an understanding of which toxins in a venom are important for an envenoming case, functional studies are needed. One such approach is toxicovenomics (see Figure 1), which was introduced in 2015 in a study of Black mamba (Dendroaspis polylepis) venom with the aim of identifying key toxins to be neutralized by effective antivenom [90]. In this study, the Toxicity Score [11] was employed which can be calculated for venom toxins and fractions (containing toxin mixtures) based on their abundance and potency. The Toxicity Scores can be used to rank the toxins or fractions according to their medical importance (typically judged by lethality in mice), although the difficulty of isolating certain toxins, such as Snake Venom Metalloproteases (SVMPs) somewhat hinder its use 196 for some venoms [11]. Geographical and intraspecies variation may give rise to slightly different 197 estimates of quantitative venom proteomes, which may, in turn, affect the Toxicity Scores for toxins 198 in venom. Additionally, the presence of toxin synergism [91] in some snake venoms (such as the 199 Green mamba, Dendroaspis angisticeps [92]) may further obscure the identification of which toxins 200 are key neutralization targets. However, when used conservatively to select the toxins which are 
essential to neutralize in order to abrogate overall venom toxicity, the toxicovenomics approach may provide a robust roadmap for antitoxin discovery. So far only elapid snake species from the Naja, Dendroaspis, and Aipysurus genera have been investigated by toxicovenomics [18,90,92-94]. However, researchers from Mexico have recently employed a similar approach for selecting which toxins from Mexican scorpions to focus antibody discovery efforts on [53].

\section{Understanding cross-reactivity by antivenomics and high-density peptide microarray}

technology

In addition to employing proteomics tools to gain a more complete understanding of whole venoms and which toxins to neutralize with novel antivenom components, it may be beneficial to harness

211 omics technologies to assess antivenoms and antitoxins to guide their development. A particularly 212 important feature for toxin-neutralizing components is their ability to (selectively) cross-neutralize 213 entire (sub)families of venom toxins, as this allows for a decreased number of antitoxins needed in a novel antivenom. Traditionally, most studies focusing on cross-reactivity and cross-neutralization

215 have been based on ELISA, enzymatic in vitro assays, and in vivo rodent assays. However, new 216 technologies emerging within the antibody field allow for more holistic and high-throughput assessments of cross-reactivity.

One of the main issues with assessing antibodies by ELISA is that cross-reactivity often correlates poorly with cross-neutralization. As a solution to this, "antivenomics" has been 220 developed based on the same methodology as venomics $[95,96]$. In the antivenomics approach, 221 whole venom is pre-incubated with beads coated with antivenom antibodies, before both bound and 222 unbound venom components are analyzed by Reversed-Phase High-Performance Liquid 223 Chromatography (RP-HPLC) and compared with the RP-HPLC chromatogram and proteomic 224 analysis of the whole venom (see Figure 2) [97]. This approach, which has so far only been used for 
serum-based antivenoms, allows for a holistic assessment of the binding capacity of antivenoms against different venom components, which may further be used to assess (potential) crossreactivity to toxins from other snake species that the antivenom was not raised against $[78,96]$. Nevertheless, the methodology should, in theory, be just as useful for assessing cross-reactivity of mAbs. Antivenomic studies have been performed on antivenoms against a range of different snake species from Europe, Asia, Oceania, and Latin America [87,98-104]. They are yet to be performed on non-snake species, possibly owing to the scarcity of venoms from smaller venomous animals.

To obtain a more detailed molecular view of cross-reactivity, immunoreactivity of antivenoms has also been evaluated using synthetic linear peptides derived from amino acid sequences of spider, scorpion, and snake toxins [105-109]. Generally, these studies have been quite meticulous and low throughput, but recently a novel high-throughput approach was introduced based on high-density peptide microarray technology (see Figure 3) [110]. In this pioneering study, the cross-reactivity of three different antivenoms against sub-Saharan African snake species was assessed and the linear elements of epitopes for all 82 reported neurotoxins from the Dendroaspis and Naja genera mapped simultaneously in one experiment. Although both the previous approaches and the more recent high-throughput techniques have so far only been employed in the assessment 241 of serum-based antivenoms, their applicability to characterization of mAbs is known from other fields $[111,112]$.

The feasibility of assessing both monoclonal and oligoclonal antibodies using both 244 antivenomics and high-density peptide microarrays may possibly be instrumental for in vitro 245 assessment of novel recombinant antivenoms, to reduce cost, guide development, and reduce the 246 amount of preclinical work needed.

\section{Conclusion}


249 Envenomings by venomous animals are one of the therapeutic areas, where medicines based on 250 animal sera are still in use. Different approaches have been tested and reported in the pursuit of 251 developing fundamentally novel antivenoms. These approaches have involved design of novel 252 immunogens (synthetic epitope DNA strings, synthetic linear peptides, and recombinant toxins and 253 toxids), the use of small molecule inhibitors against enzymatic toxins, isolation and preclinical 254 testing of endogenous animal proteins with toxin-neutralizing capabilities, and various recombinant 255 antibody formats. Other binding proteins exist that could be harnessed, but these are yet to be 256 employed within antivenom development. The most promising approach is likely to be the use of 257 mixtures of (human or camelid) mAbs due to their versatility, high target affinity, low 258 immunogenicity, and decreasing cost of production.

Irrespective of the approach employed, antivenom development efforts may benefit 260 significantly by being guided by different omics technologies. Genomics and transcriptomics are 261 excellent tools for uncovering novel animal toxins and investigating venom evolution. However, the 262 state of the art remains to be venom proteomics (particularly venomics and toxicovenomics), which 263 provides a better overview of venom compositions and what toxin targets are essential to neutralize 264 in envenoming cases. Finally, the use of antivenomics and high-density peptide microarray 265 technology may be exploited to gain in-depth understanding of antivenom and antibody specificity 266 and cross-reactivity.

\section{Acknowledgements}

269 Thanks go to Mia Øhlenschlæger for proof-reading.

\section{$271 \quad$ Funding}


272 This work was supported by the Novo Nordisk Foundation (NNF16OC0019248) for financial 273 support. 


\section{References}

[1] Gutiérrez JM, Williams D, Fan HW, Warrell DA. Snakebite envenoming from a global perspective: Towards an integrated approach. Toxicon 2010;56:1223-35. doi:10.1016/j.toxicon.2009.11.020.

[2] Harrison RA, Cook DA, Renjifo C, Casewell NR, Currier RB, Wagstaff SC. Research strategies to improve snakebite treatment: Challenges and progress. J Proteomics 2011;74:1768-80. doi:10.1016/j.jprot.2011.06.019.

[3] Harrison RA, Gutiérrez JM. Priority Actions and Progress to Substantially and Sustainably Reduce the Mortality, Morbidity and Socioeconomic Burden of Tropical Snakebite. Toxins 2016;8. doi:10.3390/toxins8120351.

[4] David Warrell, José María Gutiérrez, A. Padilla. Rabies and Envenomings: a Neglected Public Health Issue: Report of a Consultative Meeting. Geneva: World Health Organization; 2007.

[5] Diaz JH. The Global Epidemiology, Syndromic Classification, Management, and Prevention of Spider Bites. Am J Trop Med Hyg 2004;71:239-50.

[6] Carmo AO, Chatzaki M, Horta CCR, Magalhães BF, Oliveira-Mendes BBR, ChávezOlórtegui $\mathrm{C}$, et al. Evolution of alternative methodologies of scorpion antivenoms production. Toxicon 2015;97:64-74. doi:10.1016/j.toxicon.2015.02.007.

[7] Fatima Laraba-Djebari, Sonia Adi-Bessalem, Djelila Hammoudi-Triki. Scorpion Venoms: Pathogenesis and Biotherapies. Toxinology - Scorpion Venoms, vol. 4, Dordrecht Heidelberg New York London: Springer; 2015, p. 580.

[8] Laustsen AH, Engmark M, Milbo C, Johannesen J, Lomonte B, Gutiérrez JM, et al. From Fangs to Pharmacology: The Future of Snakebite Envenoming Therapy. Curr Pharm Des 2016;22:5270-93.

[9] Laustsen AH, Solà M, Jappe EC, Oscoz S, Lauridsen LP, Engmark M. Biotechnological Trends in Spider and Scorpion Antivenom Development. Toxins 2016;8:226. doi:10.3390/toxins 8080226.

[10] Gutiérrez JM, León G, Lomonte B, Angulo Y. Antivenoms for snakebite envenomings. Inflamm Allergy Drug Targets 2011;10:369-80.

[11] Laustsen AH, Lohse B, Lomonte B, Engmark M, Gutiérrez JM. Selecting key toxins for focused development of elapid snake antivenoms and inhibitors guided by a Toxicity Score. Toxicon 2015;104:43-5. doi:10.1016/j.toxicon.2015.07.334.

[12] Calvete JJ. Proteomic tools against the neglected pathology of snake bite envenoming. Expert Rev Proteomics 2011;8:739-58. doi:10.1586/epr.11.61.

[13] Calvete JJ, Lomonte B. A bright future for integrative venomics. Toxicon 2015;107, Part B:159-62. doi:10.1016/j.toxicon.2015.10.024.

[14] Warrell DA. Clinical toxicology of snakebite in Asia. In: Meier J, White J, editors. Handb. Clin. Toxicol. Anim. Venoms Poisons, Boca Raton: CRC Press; 1995, p. 493-594.

[15] Warrell DA. Snakebites in Central and South America: Epidemiology, clinical features, and clinical management. In: Brodie III ED, editor. Venom. Reptil. West. Hemisphere, Ithaca, NY: Cornell University Press; 2004, p. 709-61.

[16] Laustsen AH, Engmark M, Clouser C, Timberlake S, Vigneault F, Gutiérrez JM, et al. Exploration of immunoglobulin transcriptomes from mice immunized with three-finger 
toxins and phospholipases A2 from the Central American coral snake, Micrurus nigrocinctus. PeerJ 2017;5:e2924. doi:10.7717/peerj.2924.

[17] Alape-Girón A, Sanz L, Escolano J, Flores-Díaz M, Madrigal M, Sasa M, et al. Snake Venomics of the Lancehead Pitviper Bothrops asper: Geographic, Individual, and Ontogenetic Variations. J Proteome Res 2008;7:3556-71. doi:10.1021/pr800332p.

[18] Laustsen AH, Gutiérrez JM, Rasmussen AR, Engmark M, Gravlund P, Sanders KL, et al. Danger in the reef: Proteome, toxicity, and neutralization of the venom of the olive sea snake, Aipysurus laevis. Toxicon 2015;107, Part B:187-96. doi:10.1016/j.toxicon.2015.07.008.

[19] Wagstaff SC, Laing GD, Theakston RDG, Papaspyridis C, Harrison RA. Bioinformatics and Multiepitope DNA Immunization to Design Rational Snake Antivenom. PLoS Med 2006;5:e209. doi:10.1371/journal.pmed.0030184.

[20] Calderon-Aranda ES, Selisko B, York EJ, Gurrola GB, Stewart JM, Possani LD. Mapping of an epitope recognized by a neutralizing monoclonal antibody specific to toxin $\mathrm{Cn} 2$ from the scorpion Centruroides noxius, using discontinuous synthetic peptides. Eur J Biochem 1999;264:746-55. doi:10.1046/j.1432-1327.1999.00620.x.

[21] Guatimosim SCF, Kalapothakis E, Diniz CR, Chávez-Olórtegui C. Induction of neutralizing antibodies against Tityus serrulatus toxins by immunization with a recombinant nontoxic protein. Toxicon 2000;38:113-21. doi:10.1016/S0041-0101(99)00138-5.

[22] Lewin M, Samuel S, Merkel J, Bickler P. Varespladib (LY315920) Appears to Be a Potent, Broad-Spectrum, Inhibitor of Snake Venom Phospholipase A2 and a Possible Pre-Referral Treatment for Envenomation. Toxins 2016;8. doi:10.3390/toxins8090248.

[23] Howes J-M, Theakston RDG, Laing GD. Neutralization of the haemorrhagic activities of viperine snake venoms and venom metalloproteinases using synthetic peptide inhibitors and chelators. Toxicon Off J Int Soc Toxinology 2007;49:734-9. doi:10.1016/j.toxicon.2006.11.020.

[24] Feng L, Gao R, Gopalakrishnakone P. Isolation and characterization of a hyaluronidase from the venom of Chinese red scorpion Buthus martensi. Comp Biochem Physiol Part C Toxicol Pharmacol 2008;148:250-7. doi:10.1016/j.cbpc.2008.06.003.

[25] Morey SS, Kiran KM, Gadag JR. Purification and properties of hyaluronidase from Palamneus gravimanus (Indian black scorpion) venom. Toxicon 2006;47:188-95. doi:10.1016/j.toxicon.2005.10.014.

[26] Ramanaiah, M., Parthasarathy, Pr., Venkaiah, B. Isolation and characterization of hyaluronidase from scorpion (Heterometrus fulvipes) venom. Biochem Int 1989;20:301-10.

[27] Soares AM, Ticli FK, Marcussi S, Lourenço MV, Januário AH, Sampaio SV, et al. Medicinal plants with inhibitory properties against snake venoms. Curr Med Chem 2005;12:2625-41.

[28] Trento EP, Garcia OS, Rucavado A, França SC, Batalini C, Arantes EC, et al. Inhibitory properties of the anti-bothropic complex from Didelphis albiventris serum on toxic and pharmacological actions of metalloproteases and myotoxins from Bothrops asper venom. Biochem Pharmacol 2001;62:1521-9.

[29] Neves-Ferreira AGC, Perales J, Fox JW, Shannon JD, Makino DL, Garratt RC, et al. Structural and functional analyses of DM43, a snake venom metalloproteinase inhibitor from Didelphis marsupialis serum. J Biol Chem 2002;277:13129-37. doi:10.1074/jbc.M200589200.

[30] Neves-Ferreira AG, Perales J, Ovadia M, Moussatché H, Domont GB. Inhibitory properties of the antibothropic complex from the South American opossum (Didelphis marsupialis) serum. Toxicon Off J Int Soc Toxinology 1997;35:849-63. 
[31] Borkow G, Gutierrez JM, Ovadia M. A potent antihemorrhagin in the serum of the nonpoisonous water snake Natrix tessellata: isolation, characterization and mechanism of neutralization. Biochim Biophys Acta 1994;1201:482-90.

[32] Lizano S, Lomonte B, Fox JW, Gutiérrez JM. Biochemical characterization and pharmacological properties of a phospholipase A2 myotoxin inhibitor from the plasma of the snake Bothrops asper. Biochem J 1997;326 ( Pt 3):853-9.

[33] Borkow G, Gutierrez JM, Ovadia M. Isolation, characterization and mode of neutralization of a potent antihemorrhagic factor from the serum of the snake Bothrops asper. Biochim Biophys Acta 1995;1245:232-8.

[34] Lomonte B, Cerdas L, Gené JA, Gutiérrez JM. Neutralization of local effects of the terciopelo (Bothrops asper) venom by blood serum of the colubrid snake Clelia clelia. Toxicon Off J Int Soc Toxinology 1982;20:571-9.

[35] Thwin MM, Gopalakrishnakone P. Snake envenomation and protective natural endogenous proteins: a mini review of the recent developments (1991-1997). Toxicon Off J Int Soc Toxinology 1998;36:1471-82.

[36] Biardi JE, Coss RG, Smith DG. California ground squirrel (Spermophilus beecheyi) blood sera inhibits crotalid venom proteolytic activity. Toxicon Off J Int Soc Toxinology 2000;38:713-21.

[37] Stumpp MT, Binz HK, Amstutz P. DARPins: a new generation of protein therapeutics. Drug Discov Today 2008;13:695-701. doi:10.1016/j.drudis.2008.04.013.

[38] Rasool M, Malik A, Hussain M, Haq KA, Butt K, Basit A, et al. DARPins Bioengineering and its Theranostic Approaches: Emerging Trends in Protein Engineering. Curr Pharm Des 2016.

[39] Varadamsetty G, Tremmel D, Hansen S, Parmeggiani F, Plückthun A. Designed Armadillo repeat proteins: library generation, characterization and selection of peptide binders with high specificity. J Mol Biol 2012;424:68-87. doi:10.1016/j.jmb.2012.08.029.

[40] Béhar G, Renodon-Cornière A, Mouratou B, Pecorari F. Affitins as robust tailored reagents for affinity chromatography purification of antibodies and non-immunoglobulin proteins. $\mathrm{J}$ Chromatogr A 2016;1441:44-51. doi:10.1016/j.chroma.2016.02.068.

[41] Pacheco S, Béhar G, Maillasson M, Mouratou B, Pecorari F. Affinity transfer to the archaeal extremophilic Sac7d protein by insertion of a CDR. Protein Eng Des Sel PEDS 2014;27:4318. doi:10.1093/protein/gzu042.

[42] Correa A, Pacheco S, Mechaly AE, Obal G, Béhar G, Mouratou B, et al. Potent and Specific Inhibition of Glycosidases by Small Artificial Binding Proteins (Affitins). PLoS ONE 2014;9. doi:10.1371/journal.pone.0097438.

[43] Tiede C, Tang AAS, Deacon SE, Mandal U, Nettleship JE, Owen RL, et al. Adhiron: a stable and versatile peptide display scaffold for molecular recognition applications. Protein Eng Des Sel PEDS 2014;27:145-55. doi:10.1093/protein/gzu007.

[44] Schiefner A, Skerra A. The menagerie of human lipocalins: a natural protein scaffold for molecular recognition of physiological compounds. Acc Chem Res 2015;48:976-85. doi:10.1021/ar5003973.

[45] Simeon R, Chen Z. In vitro-engineered non-antibody protein therapeutics. Protein Cell 2017. doi:10.1007/s13238-017-0386-6.

[46] Pessenda G, Silva LC, Campos LB, Pacello EM, Pucca MB, Martinez EZ, et al. Human scFv antibodies (Afribumabs) against Africanized bee venom: Advances in melittin recognition. Toxicon 2016;112:59-67. doi:10.1016/j.toxicon.2016.01.062. 
[47] Boulain JC, Ménez A, Couderc J, Faure G, Liacopoulos P, Fromageot P. Neutralizing monoclonal antibody specific for Naja nigricollis toxin alpha: preparation, characterization, and localization of the antigenic binding site. Biochemistry (Mosc) 1982;21:2910-5.

[48] Roncolato EC, Campos LB, Pessenda G, Costa e Silva L, Furtado GP, Barbosa JE. Phage display as a novel promising antivenom therapy: A review. Toxicon 2015;93:79-84. doi:10.1016/j.toxicon.2014.11.001.

[49] Laustsen AH. Recombinant antivenoms. 1st ed. Copenhagen, Denmark: University of Copenhagen; 2016.

[50] Pucca MB, Zoccal KF, Roncolato EC, Bertolini TB, Campos LB, Cologna CT, et al. Serrumab: A human monoclonal antibody that counters the biochemical and immunological effects of Tityus serrulatus venom. J Immunotoxicol 2012;9:173-83. doi:10.3109/1547691X.2011.649220.

[51] Pucca MB, Cerni FA, Peigneur S, Arantes EC, Tytgat J, Barbosa JE. Serrumab: A novel human single chain-fragment antibody with multiple scorpion toxin-neutralizing capacities. J Immunotoxicol 2014;11:133-40. doi:10.3109/1547691X.2013.809175.

[52] Roncolato EC, Pucca MB, Funayama JC, Bertolini TB, Campos LB, Barbosa JE. Human antibody fragments specific for Bothrops jararacussu venom reduce the toxicity of other Bothrops sp. venoms. J Immunotoxicol 2013;10:160-8. doi:10.3109/1547691X.2012.703253.

[53] Rodríguez-Rodríguez ER, Olamendi-Portugal T, Serrano-Posada H, Arredondo-López JN, Gómez-Ramírez I, Fernández-Taboada G, et al. Broadening the neutralizing capacity of a family of antibody fragments against different toxins from Mexican scorpions. Toxicon 2016;119:52-63. doi:10.1016/j.toxicon.2016.05.011.

[54] Rodríguez-Rodríguez ER, Ledezma-Candanoza LM, Contreras-Ferrat LG, OlamendiPortugal T, Possani LD, Becerril B, et al. A Single Mutation in Framework 2 of the Heavy Variable Domain Improves the Properties of a Diabody and a Related Single-Chain Antibody. J Mol Biol 2012;423:337-50. doi:10.1016/j.jmb.2012.07.007.

[55] di Tommaso A, Juste MO, Martin-Eauclaire M-F, Dimier-Poisson I, Billiald P, Aubrey N. Diabody Mixture Providing Full Protection against Experimental Scorpion Envenoming with Crude Androctonus australis Venom. J Biol Chem 2012;287:14149-56. doi:10.1074/jbc.M112.348912.

[56] Abderrazek RB, Hmila I, Vincke C, Benlasfar Z, Pellis M, Dabbek H, et al. Identification of potent nanobodies to neutralize the most poisonous polypeptide from scorpion venom. Biochem J 2009;424:263-72. doi:10.1042/BJ20090697.

[57] Hmila I, Abdallah R BA-B, Saerens D, Benlasfar Z, Conrath K, Ayeb ME, et al. VHH, bivalent domains and chimeric Heavy chain-only antibodies with high neutralizing efficacy for scorpion toxin AahI'. Mol Immunol 2008;45:3847-56. doi:10.1016/j.molimm.2008.04.011.

[58] Hmila I, Cosyns B, Tounsi H, Roosens B, Caveliers V, Abderrazek RB, et al. Pre-clinical studies of toxin-specific Nanobodies: Evidence of in vivo efficacy to prevent fatal disturbances provoked by scorpion envenoming. Toxicol Appl Pharmacol 2012;264:222-31. doi:10.1016/j.taap.2012.07.033.

[59] Stewart CS, MacKenzie CR, Hall JC. Isolation, characterization and pentamerization of alpha-cobrotoxin specific single-domain antibodies from a naïve phage display library: preliminary findings for antivenom development. Toxicon Off J Int Soc Toxinology 2007;49:699-709. doi:10.1016/j.toxicon.2006.11.023.

[60] Chavanayarn C, Thanongsaksrikul J, Thueng-in K, Bangphoomi K, Sookrung N, Chaicumpa W. Humanized-Single Domain Antibodies (VH/VHH) that Bound Specifically to Naja 
kaouthia Phospholipase A2 and Neutralized the Enzymatic Activity. Toxins 2012;4:554-67. doi:10.3390/toxins4070554.

[61] Hmila I, Saerens D, Abderrazek RB, Vincke C, Abidi N, Benlasfar Z, et al. A bispecific nanobody to provide full protection against lethal scorpion envenoming. FASEB J 2010;24:3479-89. doi:10.1096/fj.09-148213.

[62] Richard G, Meyers AJ, McLean MD, Arbabi-Ghahroudi M, MacKenzie R, Hall JC. In Vivo Neutralization of $\alpha$-Cobratoxin with High-Affinity Llama Single-Domain Antibodies (VHHs) and a VHH-Fc Antibody. PLoS ONE 2013;8:e69495. doi:10.1371/journal.pone.0069495.

[63] Ringel M, Tollman P, Hersch G, Schulze U. Does size matter in R\&D productivity? If not, what does? Nat Rev Drug Discov 2013;12:901-2. doi:10.1038/nrd4164.

[64] Laustsen AH, Johansen KH, Engmark M, Andersen MR. Snakebites: costing recombinant antivenoms. Nature 2016;538:41. doi:10.1038/538041e.

[65] Laustsen AH, Johansen KH, Engmark M, Andersen MR. Recombinant snakebite antivenoms: A cost-competitive solution to a neglected tropical disease? PLoS Negl Trop Dis 2017;11:e0005361. doi:10.1371/journal.pntd.0005361.

[66] Kelley B. Very large scale monoclonal antibody purification: the case for conventional unit operations. Biotechnol Prog 2007;23:995-1008. doi:10.1021/bp070117s.

[67] Vonk FJ, Casewell NR, Henkel CV, Heimberg AM, Jansen HJ, McCleary RJR, et al. The king cobra genome reveals dynamic gene evolution and adaptation in the snake venom system. Proc Natl Acad Sci 2013;110:20651-6. doi:10.1073/pnas.1314702110.

[68] Castoe TA, Koning APJ de, Hall KT, Card DC, Schield DR, Fujita MK, et al. The Burmese python genome reveals the molecular basis for extreme adaptation in snakes. Proc Natl Acad Sci 2013;110:20645-50. doi:10.1073/pnas.1314475110.

[69] Sanggaard KW, Bechsgaard JS, Fang X, Duan J, Dyrlund TF, Gupta V, et al. Spider genomes provide insight into composition and evolution of venom and silk. Nat Commun 2014;5. doi:10.1038/ncomms4765.

[70] Gendreau KL, Haney RA, Schwager EE, Wierschin T, Stanke M, Richards S, et al. House spider genome uncovers evolutionary shifts in the diversity and expression of black widow venom proteins associated with extreme toxicity. BMC Genomics 2017;18:178. doi:10.1186/s12864-017-3551-7.

[71] Cao Z, Yu Y, Wu Y, Hao P, Di Z, He Y, et al. The genome of Mesobuthus martensii reveals a unique adaptation model of arthropods. Nat Commun 2013;4:2602. doi:10.1038/ncomms3602.

[72] Beye M, Gattermeier I, Hasselmann M, Gempe T, Schioett M, Baines JF, et al. Exceptionally high levels of recombination across the honey bee genome. Genome Res 2006;16:1339-44. doi:10.1101/gr.5680406.

[73] Haider S, Pal R. Integrated Analysis of Transcriptomic and Proteomic Data. Curr Genomics 2013;14:91-110. doi:10.2174/1389202911314020003.

[74] Durban J, Juárez P, Angulo Y, Lomonte B, Flores-Diaz M, Alape-Girón A, et al. Profiling the venom gland transcriptomes of Costa Rican snakes by 454 pyrosequencing. BMC Genomics 2011;12:259. doi:10.1186/1471-2164-12-259.

[75] Tan CH, Tan KY, Fung SY, Tan NH. Venom-gland transcriptome and venom proteome of the Malaysian king cobra (Ophiophagus hannah). BMC Genomics 2015;16:687. doi:10.1186/s12864-015-1828-2.

[76] Tan KY, Tan CH, Chanhome L, Tan NH. Comparative venom gland transcriptomics of Naja kaouthia (monocled cobra) from Malaysia and Thailand: elucidating geographical venom variation and insights into sequence novelty. PeerJ 2017;5:e3142. doi:10.7717/peerj.3142. 
[77] Calvete JJ. Next-generation snake venomics: protein-locus resolution through venom proteome decomplexation. Expert Rev Proteomics 2014;11:315-29. doi:10.1586/14789450.2014.900447.

[78] Calvete JJ. Snake venomics: From the inventory of toxins to biology. Toxicon 2013;75:4462. doi:10.1016/j.toxicon.2013.03.020.

[79] Gibbs HL, Sanz L, Calvete JJ. Snake population venomics: proteomics-based analyses of individual variation reveals significant gene regulation effects on venom protein expression in Sistrurus rattlesnakes. J Mol Evol 2009;68:113-25. doi:10.1007/s00239-008-9186-1.

[80] Gutiérrez JM, Lomonte B, León G, Alape-Girón A, Flores-Díaz M, Sanz L, et al. Snake venomics and antivenomics: Proteomic tools in the design and control of antivenoms for the treatment of snakebite envenoming. J Proteomics 2009;72:165-82. doi:10.1016/j.jprot.2009.01.008.

[81] Warrell DA, Gutiérrez JM, Calvete JJ, Williams D. New approaches \& technologies of venomics to meet the challenge of human envenoming by snakebites in India. Indian J Med Res 2013;138:38-59.

[82] Petras D, Heiss P, Harrison RA, Süssmuth RD, Calvete JJ. Top-down venomics of the East African green mamba, Dendroaspis angusticeps, and the black mamba, Dendroaspis polylepis, highlight the complexity of their toxin arsenals. J Proteomics 2016;146:148-64. doi:10.1016/j.jprot.2016.06.018.

[83] Tan CH, Tan KY, Yap MKK, Tan NH. Venomics of Tropidolaemus wagleri, the sexually dimorphic temple pit viper: Unveiling a deeply conserved atypical toxin arsenal. Sci Rep 2017;7:43237. doi:10.1038/srep43237.

[84] Latinović Z, Leonardi A, Šribar J, Sajevic T, Žužek MC, Frangež R, et al. Venomics of Vipera berus berus to explain differences in pathology elicited by Vipera ammodytes ammodytes envenomation: Therapeutic implications. J Proteomics 2016;146:34-47. doi:10.1016/j.jprot.2016.06.020.

[85] Tan NH, Wong KY, Tan CH. Venomics of Naja sputatrix, the Javan spitting cobra: A short neurotoxin-driven venom needing improved antivenom neutralization. J Proteomics 2017;157:18-32. doi:10.1016/j.jprot.2017.01.018.

[86] Tang ELH, Tan CH, Fung SY, Tan NH. Venomics of Calloselasma rhodostoma, the Malayan pit viper: A complex toxin arsenal unraveled. J Proteomics 2016;148:44-56. doi:10.1016/j.jprot.2016.07.006.

[87] Gay C, Sanz L, Calvete JJ, Pla D. Snake Venomics and Antivenomics of Bothrops diporus, a Medically Important Pitviper in Northeastern Argentina. Toxins 2015;8. doi:10.3390/toxins8010009.

[88] Tan CH, Fung SY, Yap MKK, Leong PK, Liew JL, Tan NH. Unveiling the elusive and exotic: Venomics of the Malayan blue coral snake (Calliophis bivirgata flaviceps). $\mathrm{J}$ Proteomics 2016;132:1-12. doi:10.1016/j.jprot.2015.11.014.

[89] Reeks T, Lavergne V, Sunagar K, Jones A, Undheim E, Dunstan N, et al. Deep venomics of the Pseudonaja genus reveals inter- and intra-specific variation. J Proteomics 2016;133:20 32. doi:10.1016/j.jprot.2015.11.019.

[90] Laustsen AH, Lomonte B, Lohse B, Fernández J, Gutiérrez JM. Unveiling the nature of black mamba (Dendroaspis polylepis) venom through venomics and antivenom immunoprofiling: Identification of key toxin targets for antivenom development. J Proteomics 2015;119:12642. doi:10.1016/j.jprot.2015.02.002.

[91] Laustsen AH. Toxin synergism in snake venoms. Toxin Rev 2016;35:165-70. doi:10.1080/15569543.2016.1220397. 
[92] Lauridsen LP, Laustsen AH, Lomonte B, Gutiérrez JM. Toxicovenomics and antivenom profiling of the Eastern green mamba snake (Dendroaspis angusticeps). J Proteomics 2016;136:248-61. doi:10.1016/j.jprot.2016.02.003.

[93] Lauridsen LP, Laustsen AH, Lomonte B, Gutiérrez JM. Exploring the venom of the forest cobra snake: Toxicovenomics and antivenom profiling of Naja melanoleuca. J Proteomics 2016;150:98-108. doi:10.1016/j.jprot.2016.08.024.

[94] Laustsen AH, Gutiérrez JM, Lohse B, Rasmussen AR, Fernández J, Milbo C, et al. Snake venomics of monocled cobra (Naja kaouthia) and investigation of human IgG response against venom toxins. Toxicon 2015;99:23-35. doi:10.1016/j.toxicon.2015.03.001.

[95] Calvete JJ. Antivenomics and venom phenotyping: A marriage of convenience to address the performance and range of clinical use of antivenoms. Toxicon 2010;56:1284-91. doi:10.1016/j.toxicon.2009.12.015.

[96] Gutiérrez JM, Lomonte B, Sanz L, Calvete JJ, Pla D. Immunological profile of antivenoms: Preclinical analysis of the efficacy of a polyspecific antivenom through antivenomics and neutralization assays. J Proteomics 2014;105:340-50. doi:10.1016/j.jprot.2014.02.021.

[97] Calvete JJ, Sanz L, Angulo Y, Lomonte B, Gutiérrez JM. Venoms, venomics, antivenomics. FEBS Lett 2009;583:1736-43. doi:10.1016/j.febslet.2009.03.029.

[98] Calvete JJ, Cid P, Sanz L, Segura álvaro, Villalta M, Herrera M, et al. Antivenomic Assessment of the Immunological Reactivity of EchiTAb-Plus-ICP, an Antivenom for the Treatment of Snakebite Envenoming in Sub-Saharan Africa. Am J Trop Med Hyg 2010;82:1194-201. doi:10.4269/ajtmh.2010.09-0733.

[99] Xu N, Zhao H-Y, Yin Y, Shen S-S, Shan L-L, Chen C-X, et al. Combined venomics, antivenomics and venom gland transcriptome analysis of the monocoled cobra (Naja kaouthia) from China. J Proteomics 2017. doi:10.1016/j.jprot.2017.02.018.

[100] Calvete JJ, Arias AS, Rodríguez Y, Quesada-Bernat S, Sánchez LV, Chippaux JP, et al. Preclinical evaluation of three polyspecific antivenoms against the venom of Echis ocellatus: Neutralization of toxic activities and antivenomics. Toxicon Off J Int Soc Toxinology 2016;119:280-8. doi:10.1016/j.toxicon.2016.06.022.

[101] Goncalves-Machado L. Combined venomics, venom gland transcriptomics, bioactivities, and antivenomics of two Bothrops jararaca populations from geographic isolated regions within the Brazilian Atlantic rainforest. J Proteomics 2016;135:73-89. doi:10.1016/j.jprot.2015.04.029.

[102] Pla D, Bande BW, Welton RE, Paiva OK, Sanz L, Segura Á, et al. Proteomics and antivenomics of Papuan black snake (Pseudechis papuanus) venom with analysis of its toxicological profile and the preclinical efficacy of Australian antivenoms. J Proteomics 2017;150:201-15. doi:10.1016/j.jprot.2016.09.007.

[103] Pla D, Calvete JJ, Elosua C, Paniagua J. Antivenomics of a European vipera antivenom. Toxicon 2016;119:371. doi:10.1016/j.toxicon.2016.06.025.

[104] Pla D, Calvete JJ, Elosua C, Paniagua J. Antivenomics of a sub-saharan Africa antivenom antivipmyn Africa. Toxicon 2016;119:371-2. doi:10.1016/j.toxicon.2016.06.026.

[105] De-Simone SG, Napoleão-Pego P, Teixeira-Pinto LAL, Santos JDL, De-Simone TS, Melgarejo AR, et al. Linear B-cell epitopes in BthTX-1, BthTX-II and BthA-1, phospholipase A2's from Bothrops jararacussu snake venom, recognized by therapeutically neutralizing commercial horse antivenom. Toxicon 2013;72:90-101. doi:10.1016/j.toxicon.2013.06.004.

[106] Lomonte B. Identification of linear B-cell epitopes on myotoxin II, a Lys49 phospholipase A2 homologue from Bothrops asper snake venom. Toxicon 2012;60:782-90. doi:10.1016/j.toxicon.2012.05.028. 
[107] Castro KL, Duarte CG, Ramos HR, Machado de Avila RA, Schneider FS, Oliveira D, et al. Identification and characterization of B-cell epitopes of 3FTx and PLA2 toxins from Micrurus corallinus snake venom. Toxicon 2015;93:51-60. doi:10.1016/j.toxicon.2014.10.015.

[108] Maria WS, Velarde DT, Alvarenga LM, Nguyen C, Villard S, Granier C, et al. Localization of epitopes in the toxins of Tityus serrulatus scorpions and neutralizing potential of therapeutic antivenoms. Toxicon 2005;46:210-7. doi:10.1016/j.toxicon.2005.03.024.

[109] Ramada JS, Becker-Finco A, Minozzo JC, Felicori LF, Machado de Avila RA, Molina F, et al. Synthetic peptides for in vitro evaluation of the neutralizing potency of Loxosceles antivenoms. Toxicon 2013;73:47-55. doi:10.1016/j.toxicon.2013.07.007.

[110] Engmark M, Andersen MR, Laustsen AH, Patel J, Sullivan E, Masi F de, et al. Highthroughput immuno-profiling of mamba (Dendroaspis) venom toxin epitopes using highdensity peptide microarrays. Sci Rep 2016;6:36629. doi:10.1038/srep36629.

[111] Halperin RF, Stafford P, Johnston SA. Exploring Antibody Recognition of Sequence Space through Random-Sequence Peptide Microarrays. Mol Cell Proteomics MCP 2011;10. doi:10.1074/mcp.M110.000786.

[112] Price JV, Tangsombatvisit S, Xu G, Levy D, Baechler EC, Gozani O, et al. "On silico" peptide microarrays for high-resolution mapping of antibody epitopes and diverse proteinprotein interactions. Nat Med 2012;18:1434-40. doi:10.1038/nm.2913. 
624 Figure 1. Schematic overview of venomics and toxicovenomics. Following the venomics approach, 625 venoms are fractionated by HPLC and gel electrophoresis, and the different fractions are 626 enzymatically digested and analyzed by MALDI-TOF-TOF and bioinformatics for identification of 627 toxins. Using chromatographic data and SDS-PAGE densitometry, it is possible to quantitatively 628 estimate the venom proteome. Toxicovenomics builds upon venomics and includes in vivo toxicity 629 data, which can be used to obtain an overview of venoms as pharmacological targets for antitoxin 630 development and determine which toxins are essential to neutralize with antivenom in an 631 envenoming case.

633 Figure 2. Schematic overview of the antivenomics approach. A) First venom is passed through a 634 column containing resins that are coated with antivenom. Unbound toxins are analyzed by 635 Reversed-Phase High-Performance Liquid Chromatography (RP-HPLC). B) Bound venom toxins 636 are then eluted and likewise analyzed by RP-HPLC. C) Combined with the chromatogram and a 637 proteomic analysis of the whole venom, the two analyses provide an overview of which venom 638 toxins are readily recognized and bound by a given antivenom, and which toxins are not.

640 Figure 3. Schematic overview of how high-density peptide microarrays are designed and used for 641 the study of epitope-paratope interactions between antivenoms and animal venom toxins. 


\section{Highlights}

- nvenoming by venomous animals remain a major public health challenge in the tropics

- Biotechnological approaches are being harnessed for development of novel antivenoms

- Genomics and transcriptomics are good for uncovering novel venom toxins

- Venom proteomics is useful for identifying key toxins for neutralization by novel antivenoms

- High-density peptide microarray technology is emerging as a valuable tool in antivenom research 